\title{
An Autoethnographic Journey in Developing Post-Ableist Music Therapy
}

\author{
Carolyn May Shaw * \\ 1 New Zealand School of Music, Te Kōkīi, Victoria University of Wellington, Aotearoa, New Zealand. \\ *carolynayson@hotmail.com
}

Received: 29 April 2021 Accepted: 14 January 2022 Published: 1 March 2022

Editor: Susan Hadley Reviewers: Maren Metell, Rachel Reed

\begin{abstract}
This paper describes my journey in developing Post-Ableist Music Therapy and offers vignettes of its use in practice. In the style of an autoethnography, it recounts the way I began actively to address the ableism that was uncovered during the analysis process of my PhD research: 'Developing Post-Ableist Music Therapy: An autoethnography exploring the counterpoint of a therapist experiencing illness/disability'(Shaw, 2019). I set about developing an ethic for practice that would address ableism by using the Foucauldian tool of creating the self as a work of art. I engaged in a creative process as a way to defamiliarise and reconceptualise practice. Post-Ableist Music Therapy was developed and extended the relational ethic beyond what was present in the practice studied, by drawing on aspects of posthumanism (valuing interdependence; Braidotti, 2013), agonistic pluralism (Chambers, 2001; Cloyes, 2002; Mouffe, 2016), and increasing the incorporation of disability studies. Posthumanism was used as a foundation for PAMT (due to the ableist tendencies of humanism), which differs to current music therapy orientations. Therefore, PAMT is offered as an alternative lens in the critical orientations' apparatus: a social justice practice that is not based on empowerment and humanism, but instead on agonism and posthumanism.
\end{abstract}

Keywords: posthumanism, ableism, normalisation, agonism

\section{Introduction: Searching for a Way to Work Without a Vegetarian Having to Eat Meat.}

I had just completed the post-structural analysis for my $\mathrm{PhD}$ research (2017) where I was examining critically my experience of illness and disability ${ }^{1}$ as a music therapist (Shaw, 2019) and I was in a muddle of what to do with the hidden processes of ableism that it uncovered. I found that subtle forms of ableism and normalising practices that were experienced in my examined personal narratives were often present in my Music Therapy (MT) practice. Additionally, the analysis uncovered the presence of ableism across multiple contexts: workplaces, professional interactions, ${ }^{2}$ postgraduate education, and many MT discourses. Universalising and dichotomising narratives were found in the practice studied that supported regimes of ableism: the enforcement of the able/ 
disabled divide through many binaries (client-therapist, biology-culture, human-nonhuman, positive emotions-negative emotions, independence-dependence), limited understandings of disability based on observable identifications, success and music based on the normate ${ }^{3}$ individual, and normative humanism (Shaw, 2019). Discovering the depth of the role I played in ableism and the contextual shaping of this during my $\mathrm{PhD}$ analysis was unnerving. In the style of an autoethnography, this paper describes my journey in working through that 'unnerving muddle' towards an alternative way of practicing.

In this paper I deliberately change between using the person-first language of "person with a disability," and the political reclaiming of disability as "disabled person/ people." Person-first language stresses the importance of the person rather than the category, whereas identity-first language wishes to acknowledge that one cannot separate themselves from their disability (it is not a shameful aspect that negates them from being a person). As I explored multiple positions throughout my research, and advocate for plural identities, I use both accordingly.

Before continuing with sharing my journey that took place between 2016 until the beginning of 2018, it is helpful at this point to offer a definition of ableism. The concept of ableism is thought to have evolved in the 1960s and 1970s from the disabled people rights' movements (Albrecht, 2006; Wolbring, 2012). One understanding often used is that ableism is a form of oppression that describes the negative treatment of disabled people and leads to disablism: "the discriminatory, oppressive, or abusive behaviour arising from the belief that people who do not have certain abilities are inferior to others" (Wolbring, 2009, p. 151).

I find Campbell's (2008b, 2009) and Wolbring's (2008, 2012) definitions of ableism helpful. Both authors recognise that ableism can be another "-ism" but extend its scope and understanding beyond being related only to disabled people, making it applicable to many academic fields. Ableism is "a network of beliefs, processes and practices that produces a particular kind of self and body (the corporeal standard) that is projected as perfect, species-typical and therefore essential and fully human" (Campbell, 2009 , p. 5). It is not just a matter of negative attitudes towards disabled people, but a deep way of thinking about bodies, wholeness and a striving for perfection (Campbell, 2014). Ableism expresses the ways in which the normative ideal of mental and physical wholeness is privileged in society: promoting an unobtainable corporeal aesthetic that encourages bodily projects towards that end. Disability signifies violated "wholeness" and incompleteness (Garland-Thomson, 1997) which has been ascribed as a negative cultural icon.

Like Campbell, Wolbring (2008, 2012, 2009) contends that the dominant understanding of ableism is too limited and proposes a broadened definition. He defines ableism as:

...a set of beliefs, processes and practices that produce based on one's abilities a particular kind of understanding of oneself, one's body and one's relationship with others of one's species, other species and one's environment and includes one being judged by others. Ableism exhibits a favouritism for certain abilities that are projected as essential while at the same time labelling real or perceived deviations from-a lack of essential abilities-as a diminished state of being. (Wolbring, 2009, p. 150)

He suggests that it is one of the most socially entrenched and accepted "-isms" and one of the biggest enablers for other "-isms" (Wolbring, 2008). Wolbring employs the concept of ableism as a tool to investigate other "-isms." Ableism is used to justify sexism through the favouring of certain abilities that women are labelled not to have, for example (Wolbring, 2008). He also uses it to investigate of the relationship between human and non-human entities, eco-ableism. Ability-based judgements are factors that play out in climate summits, for example.

There seemed to be the need for developing a MT orientation that could address the under-theorisation of ableism in the profession. Recent efforts have been made towards theorising ableism in MT, such as within anti-oppressive MT (Baines, 2013), the Special 
Table 1

Comparison of the number of hits found for terms relating to oppression with "music therapy" on the 27/ $08 / 2018$

\begin{tabular}{|l|l|l|l|}
\hline & \multicolumn{1}{|c|}{$\begin{array}{c}\text { Google } \\
\text { search }\end{array}$} & \multicolumn{1}{|c|}{$\begin{array}{c}\text { Google } \\
\text { Scholar }\end{array}$} & \multicolumn{1}{|c|}{$\begin{array}{c}\text { Victoria University library search } \\
\text { engine }\end{array}$} \\
\hline “Music therapy" and racism & 383,000 & 2,100 & 851 \\
\hline "Music therapy" and sexism & 389,000 & 870 & 346 \\
\hline $\begin{array}{l}\text { "Music therapy" and heterosexual- } \\
\text { ism }\end{array}$ & 52,300 & 950 & 476 \\
\hline "Music therapy" and ageism & 51,800 & 554 & 186 \\
\hline "Music therapy" and classism & 11,900 & 161 & 92 \\
\hline “Music therapy" and ableism & 9,000 & 148 & 48 \\
\hline
\end{tabular}

Issue on MT and Disability Studies inVoices (2014, Vol.14, n. 3), critical thinking papers (Metell \& Stige, 2015) and online training courses such as McFerran's (2018) seminar on critical thinking. Alongside this, more therapists are becoming aware of alternative models of disability to that of the predominant medical model, such as the social model of disability (Gross, 2018) and other critical models that support social justice of stigmatised identities. Since finishing my $\mathrm{PhD}$ (post the journey I document here) other therapists have published about their experiences of disability and disability pride (Kalenderidis, 2020), challenged UK Health and Care Professions Council Standards of Proficiency for Arts Therapists through the lens of disability studies (Pickard, 2020), and explored implications of the neurodiversity movement (Pickard et al., 2020). However, for the most part, sources in MT theory were lacking in detailed focus on ableism during the time I was grappling with my analysis findings. I propose that this undertheorisation is due to weak engagement with disability studies (as noted by Tsiris, 2013, 2018) and the lack of open and direct acknowledgement of these theories (Shaw, 2019). For example, doing a search during my studies on Google, Google Scholar and the Victoria University of Wellington library search engine Te Waharoa demonstrated this lag of the theorisation of ableism. When searching the term "music therapy" with various forms of discrimination, there were comparatively far fewer hits for ableism, the lowest in all searches. The sources it did generate often just mention ableism in passing.

I made many attempts part way through my PhD research to address the enormity of the ableism uncovered in the practice and experiences studied. For example, increasing collaboration, changing pathologising/dehumanising language, and activism in changing Codes of Ethics and Standards of Practice in Aotearoa (Music Therapy New Zealand, 2017). But even with all the changes and actions, as Kenny (2015) has described, I still felt the "grinding and irritating feeling" (p. 465) in my gut about how to describe my practice.

When a supervisor asked me, "What are you searching for?", I replied, "I am searching for a way to do my job without a vegetarian having to eat meat," as a lot of music therapy practice went against or did not meet the ethical concerns I had. With this, I realised that I had to redefine practice in my own way (Kenny, 2015). However, there was much difficulty in doing so. My experience, work and the theories I explored were often at odds with each other (Halifax, 2009). There was not one theory that would fit: each threw certain patterns into relief and others into shadow (Halifax, 2009). I started drawing on a patchwork blanket of theories and counter discourses to cover and address the ethical concerns from dominant discourses raised in the analysis chapters. The ethical concerns consisted of issues of disability representation and lack of disabled voices in theory development; paternalism; stigmatisation and exclusion in contexts relating to MT practice and training; binary thinking and dividing practices of disabled people; anthropocentrism; dominance of humanistic thinking that excludes 
some disabled ways of being; standardisation; subjugation of immeasurable aspects of therapy (stillness, beauty, creativity, aesthetics); and the need to value the role of unpredictability, surprise, disruptions, unknowing. Some examples of counter discourses and theories drawn on in my analysis chapters (2015-2017) that sought to address these concerns included ${ }^{5}$ :

- Disability studies (Goodley, 2010),

- Field of play (Kenny, 2006)

- Resource oriented MT (Rolvsjord, 2010)

- Community Music Therapy (CoMT) (Aarø \& Stige, 2012; Ansdell, 2002)

- Queer music therapy (Bain et al., 2016)

- Feminist MT (Hadley, 2006)

- Anti-oppressive MT(Baines, 2013)

- Narrative therapy (Morgan, 2000)

- Ecological music therapy (Small, 1998)

- Indigenous health models - Te Whare Tapa Whā (Māori model of health, Durie, 1998).

- Aesthetic MT (Lee, 2003)

- Music centred approaches (Aigen, 2005)

- Posthuman approaches (Braidotti, 2013)

To accommodate and address the concerns mentioned above, such a practice would be based on the primary ethic of an increased relationality that encompasses:

- Subjectivity

- Mutuality (non-hierarchical being, partnership)

- Interdependence

- Questioning/Negative capability

- Agonism ${ }^{6}$

- Creativity and beauty

- Diversity

Like many well-intentioned relational approaches, my previous practice often spoke the language of relationships, but was still confined in some ways to the individual (Sampson, 2003). For example, individualising therapeutic concerns and not acknowledging the role of non-human agents, limited its relationality. An extended form of relationality was needed in my practice. Relational ethics insist that relationships are key to human survival and well-being and that relationships are systems that cannot be reduced to the processes of its parts (Sampson, 2003). A relational paradigm has slowly but surely overtaken self-contained individualistic views that were a large part of therapeutic practices (Sampson, 2003) and there are still ways to further extend this in practice.

With this patchwork blanket of theories and ethics in mind, the rest of this paper details my journey in how I came to redefine my practice by using the Foucauldian tool of creating the self as a work of art. Foucault states that "from the idea that the self is not given to us, I think there is only one practical consequence: we have to create ourselves as a work of art" (Foucault, 1984, p. 351). This relates to the domain of ethics in his critical ontology of ourselves, an historico-critical inquiry of oneself that also looks at how truth is constituted and the power relations within them (Foucault, 1984). During the analysis phase of my research, I predominantly focused on the domains of truth and power. This journey documented here further developed the domain of ethics. The critical ontology of ourselves should experiment with the possibility of going beyond the limits imposed on us and create something new. I engaged in a creative process as a way to defamiliarise and reconceptualise practice. 
The paper will be structured in the following way:

- "Starting with the human: from human to posthuman": This explores the basic unit of reference for the human and describes my shift away from humanism to posthumanism.

- "Person meets music: the musical posthuman": This section recounts three musical improvisations and details a creative musical journey towards the development of Post-Ableist Music Therapy (PAMT).

- "Putting it all together: Post-Ableist Music Therapy": Descriptions of PAMT and forms of ableism are given as well as vignettes demonstrating aspects of PAMT.

\section{Starting With the Person: From Human to Posthuman}

I have to start somewhere in redefining my practice. ${ }^{7}$ Or rather restart again. Redoing. Reworking. Reinventing. I go back to the beginning, "What determines our conceptions of and ways of doing MT are our basic views on the nature of the individual, or the human being" (Ruud, 2010, p. 1). What is my idea of the human person? From asking this, I recognise the foundation of humanism on which much of MT rests. Many of the MT approaches listed above that I drew on are keenly described as humanistic or describe humanistic ideals. As Ansdell \& Stige (2018) contend, the logic of humanism seems to be solidly present in contemporary MT. It has been embraced by a number of leading MT theorists (Aigen, 2014).

However, I need to rethink humanism as it limits the relational ethic of my practice with its focus on independence and the centrality of human agents. Sampson (2003) suggests that in order to have a genuinely relational practice it must be based on unconditional relationships of responsibility to others. In addition to its relational limitations, like Braidotti (2013) I found it ethically and intellectually impossible to disengage the positive elements of humanism from their problematic counterparts. In particular, its relationship with colonising and ableist tendencies of the body and psyche (Goodley, Lawthom et al., 2014). Interdependence, self-determination, choice, self-actualisation and rationality that create the humanistic subject, also inscribe these characteristics as pertaining to the "good citizen." Such ideals exclude disabled ways of being that demand interdependence, a sharing of autonomy and control and are constraining due to being unobtainable and at odds. Thus, they produce disability as "other": (ir)rational, (non)autonomous, (non)competent and dependent (Erevelles, 2011). Disability in the context of humanism stands for a "self-gone out of control, individualism run rampant: it mocks the notion of the body as compliant instrument of the limitless will and appears in the cultural imagination as ungovernable, recalcitrant, flaunting its difference as if to refute the fantasy of sameness implicit in the notion of equality" (Garland-Thomson, 1997, p. 43). In short, disabled people are excluded and struggle to be considered fully human within this discourse whilst other human bodies are validated and affirmed. Braidotti (2013) alludes to this in her first paragraph of her book on posthumanism.

Not all of us can say, with any degree of certainty, that we have always been human, or that we are only that. Some of us are not even considered fully human now, let alone at previous moments of Western social, political and scientific history. Not if by 'human' we mean that creature familiar to us from the Enlightenment and its 'legacy.' (p.1)

Problematic humanistic shaping of the human is present in the goals and successes I pursue and set in my practice. I also struggle with the emotional challenge of not meeting these humanistic standards personally.

In order to counter the humanistic ableist tendencies of the body and psyche that mark those who count or do not count as human and its limits to relationality, I need to shift from the humanistic character that dominates. I look to rebuild my foundations of practice with aspects of Braidotti's posthumanism (2013). She offers me a way to re-think the basic unit of reference for the human: posthuman subjectivity is an 
interconnected interdependent relational entity that is embodied and embedded. The posthuman subject forms an "enlarged sense of interconnection between self and others, including the non-human or 'earth' others, by removing the obstacle of self-centred individualism" (Braidotti, 2013, p. 190). This happens through renewing claim to the earth, community, global community and belonging by singular subjects through a strong sense of collectivity: fostering collaborative morality.

The posthuman subject is a non-hierarchical creative being with multiple capacities for relations of all sorts and "modes of communication by codes that transcend the linguistic sign by exceeding it in many directions" (Braidotti, 2013, p. 190). It also allows room for communication as an "embodied and impure activity based on noise, relationality, and reciprocity" (St. Pierre, 2015, p. 330) and technological voices for example through iPad programmes.

The discourse of posthumanism seems helpful to me in eschewing individualism, autonomy, and self-mastery (St. Pierre, 2015), and therefore makes more room for relationality. There is a celebration of interdependence here, not a shaming of it, or a striving away from it. All bodies are accepted with posthumanism's central demand to not be pressured by society to adopt a "normal" body (Goodley, Lawthom et al., 2014; Wolbring, 2009, 2012). The interdependency of the posthuman subject is in accordance with critical disability studies' major theme that "disability necessarily demands and affirms interdependent connections with other humans, technologies, non-human entities, communication streams and people and non-peopled networks" (Goodley, Lawthom et al., 2014, p. 348). Of importance to disability studies is the lesson that dependence is not a defining element of disability status, "rather interdependence is perhaps the defining feature of civilization" (Lubet, 2011, p. 6). The illusion of the self-governing autonomous individual, and therefore the fantasy of non-disabled, is exposed in posthumanism.

Although there is not much to go on in the music therapy literature, ${ }^{8}$ I can walk a little easier with this posthuman subject: In the figurative sense at least. In the literal sense, I am unwell again: My legs have become heavy and hard to move at times. I myself am becoming posthuman ${ }^{9}$ as my rational thought, linguistic prowess and independence gives way to something else.

My legs become my husbands. He holds my weight, moving me to the other room. The blood pressure monitor becomes another limb that informs and supports us to know when to get moving again. I feel too much to ration myself out of tears. Words, w o $\mathrm{r} \mathrm{d} \mathrm{s} \mathrm{....w} \mathrm{h}$ a t w a s t h a t w o r d...I wave my hand to his question as my brain empties the alphabet. I develop my posthuman codes of grunts and particular looks. The posthuman is disabled, interdependent with non-human and human agents, created and relieved by both. I need to become posthuman for if I stay human on this earth, I will continue with much struggle. I realise I am jumping all over the page now. This is how life currently feels. Disrupted. In short snippets.

\section{Person Meets Music: The Musical Posthuman}

Between body disruptions, I am in PhD supervision struggling to articulate a new practice. The suggestion is made to "creatively play with music" instead. It feels like the right (and only) thing to do at this juncture. Music can provide release and relief from words: to make music is to engage in a form that is not necessarily narrative driven (McCaffrey \& Edwards, 2015). It can support research by unlocking alternative ways of thinking through its facilitation of playing in the unknown (Hoskyns, 2017).

My research methodology, a post-structurally informed arts-based autoethnography, supports alternative, creative, and embodied ways of knowing. Autoethnography is "an approach to research and writing that seeks to describe and analyse (graphy) personal experience (auto) in order to understand cultural experience (ethno)" (Ellis et al., 2011, p. 1). It is a contemporary qualitative research method within the discipline of ethnography (Grant et al., 2013). It is difficult to precisely define autoethnography due to its myriad forms, approaches and creative representations (Boylorn \& Orbe, 2014). Autoethnographic research is often evocative, creative, complex and non-reductionist. 
I used an arts-based form of autoethnography, drawing on arts-based research. Viega and Forinash (2016) offer an expanded definition of ABR that highlights the diversity of approaches and current trend of including arts-based practices in any or all of the stages of research. They place more focus on the arts informing and sometimes leading the research process. An arts-based approach fits with autoethnographies "attempt to disrupt notions of normalcy in research" (Slattery, 2001, p. 389).

As well as creativity being upheld by my research methodology, many of the theories informing me while creating myself endorse the role of creativity. One of the stated criteria in posthuman ethics is making a "new link between theory and practice" that includes the central role of creativity (Braidotti, 2013, p. 191). This correlates with Lee's (2003) reminder that music therapists cannot forget to make links with the practices of music. Aesthetic MT and music-centered approaches are based on this principle. Furthermore, "faith in the creative powers of the imagination is an integral part of feminists' appraisal of lived embodied experience and the bodily roots of subjectivity" (Braidotti, 2013, p. 191). With such endorsement, my next step is to make music. To create music is to be open to all possibilities (Lee, 2003). The outcome is uncertain. This uncertainty parallels my experience of illness.

\subsection{Improvisations}

With my supervisors we engage in three improvisations: each improvisation explores one of the major areas in my analysis:

1. Ideas around success. My analysis found that limited understandings of health and disability restricted understandings of success in an educational context. Ideas of success in supported learning in NZ were based on the normate individual.

2. Dichotomies. My analysis found that dichotomies played a dominant role in the practice studied. These binaries contributed towards the enforcement of the abledisabled divide.

3. Invisibility and disclosure. My analysis found that visual and aural observational truth making of disability was privileged over the disabled person's embodied experience. Due to this and inequitable educational structures and ableist professional codes, issues of disclosure were found to be prevalent.

Following the improvisations we have a discussion. The discussions are transcribed and important ideas highlighted. From this a creative writing piece for each is created. ${ }^{10}$ The music is a joint activity that belongs to none of us, rather it is a co-production of being together. Therefore, with a relational ethic, I alone did not develop the findings to come.

In the first improvisation and creative writing, the 'elephant feet' (temple blocks) become a symbolic representation of disabling barriers. From this creative exercise, I extrapolate that a key component of good practice is the removal of ableist barriers that limit success: including how success is framed and what it can be.

From the second improvisation, discussion and creative writing process, I discover that a key role of the music therapist is to be like "The Third" ${ }^{\text {"11 }}$ : to find ways music can both facilitate moments of connection and find new spaces that differ from existing structures or spaces that are less restrictive (new and less restrictive spaces). Importantly, the description of the third revealed during the creative writing suggests an agonistic state where the productive possibilities of playing in the tensions between different structures were illuminated. I expand on this idea later in this paper. To provide further context and example, here is the full piece of writing that emerged from the second improvisation. 


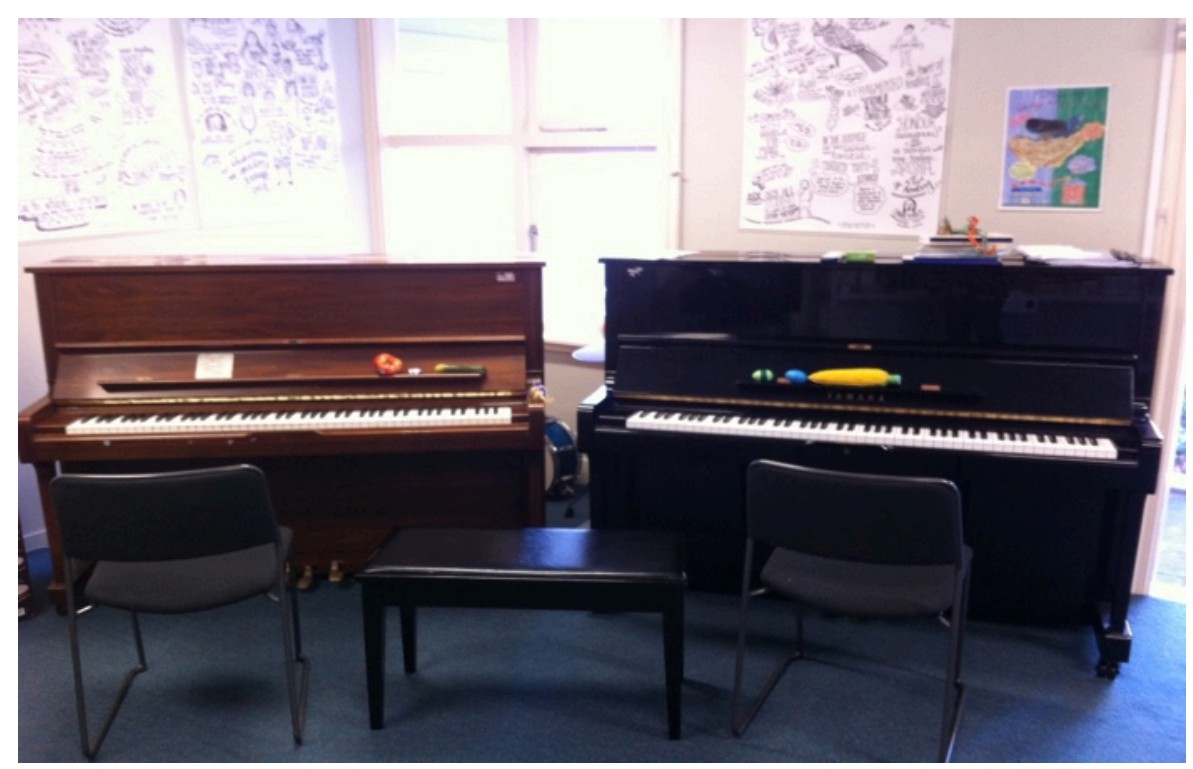

Figure 1

[Two pianos side by side]

When they started, they did not know of sides, or camps, or positions.

They stood randomly while the bells rang.

Resonating together.

One picked one piano and then another picked the other.

The third sat in the only seat left.

The one between them.

The two on separate pianos started a dialogue, or was it a debate?

From the two solid piano frames.

Toing and froing.

The third did not know which keys to play and when.

Scared of notes in the wrong place.

Or joining the wrong piano.

With this ambivalence, she randomly tested out different notes.

Surprising the others with unpredictable tone and rhythm.

She changed the direction.

Falling between the two pianos she sometimes escaped the heavy frames.

Calling the two away from their pianos as she played the bells.

But they kept playing...

Except their playing moulded into tender moments of togetherness.

One supporting the other piano's melodies.

Talking with, not to or over each other.

Perhaps unknowingly, the third kept finding "the unheard music."12

She pressed two piano keys that lay side by side.

The others took turns to copy.

There was silence between the two different notes singing together.

Space to breathe and to be undone by the clashing.

Beautiful dissonance.

When they finished, they did not know of only their side, or camp, or position.

They knew of the third's ability to connect them and of her beautiful différance. ${ }^{13}$

From the third improvisation, discussion and creative writing process, two important ways of managing invisibility and disclosure in MT stuck out for me. Firstly, cre- 
ating less disabling environments (within sessions and professional practices) may reduce some of the issues around forced intrusive disclosures that ableist environments demand. I recognise from the creative writing that forced disclosures are different from claiming a disabled identity for the self that resists normativity and challenges environments to become less disabling. Therefore, creating less disabling environments may be created both through self-driven disclosures of disabled identities AND a reduction of forced disclosure of personal detail regarding one's body and mind. Secondly, developing the ability to question your frame of reference can alter what you perceive, changing the need for disclosure and changing the visibility of hidden aspects.

\section{Putting it All Together: Post-Ableist Music Therapy (PAMT)}

I found the improvisation, discussion, and creative writing process helpful as a way of gaining clarity amongst the mass of qualitative data ${ }^{14}$ It was also helpful in creating direction and moving me outside of the dominant discourses of the practice studied. During this process, five main aspects of practice emerged as important focus areas. These were (in order of appearance):

1. The removal of ableist barriers

2. Supporting moments of connection

3. Finding new and less restrictive spaces to be in practice

4. Creating an environment and experience that is less disabling (in the sense that ableism is addressed)

\section{Questioning my frame of reference}

Reflecting on this list, I see that they are all working towards the same agenda: to "create an environment and experience that is less disabling ${ }^{15}$ " (number 4 ), through the removal of ableist barriers (number 1), supporting moments of connection (number 2), finding new and less restrictive spaces to be (number 3), and the questioning my frame of reference (number 5). Looking back at the ethical concerns and issues highlighted in the introduction, it appears that they too are accommodated within this practice focus. To create an ethic of increased relationality through subjectivity, mutuality/non-hierarchical being, interdependence, questioning/negative capability, agonism, creativity/beauty, and diversity, would support the creation of a less disabling environment in practice. The focus areas above, therefore, rely on an increased relational ethic, as barriers, disconnections, constricting spaces and normative frames are constructed through a limited humanistic relationality based on the non-disabled person.

\subsection{Post-Ableist Music Therapy Description}

To hold central the creation of a less disabling environment and experience in my practice, through focus on the aforementioned areas and enhanced relational ethic, led me to the development of what I call Post-Ableist Music Therapy (PAMT). PAMT is a creative process that seeks to work with a person and community to provide an environment and experience that is less disabling through addressing ableist barriers, exploring connections, and providing new and less restrictive spaces through primarily musical or music related experiences. It welcomes different ways of being and resists a one-size fits all approach. Instead, the people we collaborate and work with and contexts guide the process. In this way, the definition I give of PAMT cannot be too prescriptive. It is necessary that the therapist questions their frame of reference during the process to unearth and undo ableist assumptions. This is important because "We are all, regardless of our subject positions, shaped and formed by the politics of ableism" (Campbell, 2008a, p. 151). PAMT is primarily based on aspects of posthumanism to counter the ableism and limited relationality inherent in humanism. As the posthuman subject is an interconnected interdependent relational entity, it counters pursuits to- 
wards the myth of wholeness ('making the person whole') ${ }^{16}$ and doesn't hold independence as a core measure of success.

Agonism, a Foucauldian and feminist concept, is another significant aspect of PAMT. In order for therapists to question their frame of reference there is a need to foster many positions within practice. Agonism understands the struggle between ethical standpoints as a potential site of productive possibility (agonistic struggle). The tensions between discourses do not seek to be reconciled, because within agonism the tensions themselves are productive and possible starting points for developing an effective political post-ableist theory of practice (Cloyes, 2002). The permanent place of conflict between the discourses is accepted in an environment of deep respect and concern for each other: conflict and mutual admiration are present in agonism (Chambers, 2001). In this space the tussle is channeled positively, to recognise and address the ableism that leads to disablement. Foucault (1982) uses the term agonistic to refer to the role of struggle within oneself, in order to command one's self. Agonism allows for the possibility that things could be otherwise. To foster agonism in PAMT we need to increase the visibility of and use of hidden or less engaged discourses (disability studies, for example), locate and recognise the normalised subject, allow a space to be different and disabled, and allow space for flexibility and change (Shaw, 2019).

As there is no one definition that adequately describes disability, due to its heterogeneity and intersectionality. PAMT draws on multiple disability definitions: the social model (Oliver, 1996), the affirmation model (Swain \& French, 2000), the minority model, the cultural model, the biopsychosocial model (World Health Organisation, 2011), disability as identity, and the medical model. It recognises that different positions are available within each discourse that may be helpful at various times in reducing ableism. I have, perhaps controversially, included the medical model (albeit just). I recognise its shortcomings and its perpetuation of much ableism through its individualisation, deficit language, concern with norms, and pathologisation. However, I am certainly not against medication and medicine. I greatly appreciate the opportunities access to good medical intervention gives me. By keeping it in the mix of ways of understanding disability, one can draw on its focus on the particularity of the body and mind, which may be needed at times in creating understanding and reducing ableism. For example, if I explain to someone that my body doesn't allow me to walk far distances due to a particular diagnosis, they can understand why I'm declining their invitation to go on a weekend hiking trip without misunderstandings. Furthermore, I do not wish to stigmatise conditions that require pharmacological intervention. For example, pain can become unbearable and require remediation.

By using the term post-ableism, I do not intend to imply that all MT practice and theory prior to this was ableist. The term is used to name an orientation that identifies the need to undo ableist practices and for this to have an overt and central focus in MT. However, ableist statements and sentiments are found widely in MT literature, and in practice standards and codes of ethics. These need to be acknowledged in order to interrogate the violence of ableism and to speak of its injuries. Additionally, I do not offer PAMT as a way to undo what has gone before, but rather as a theoretical orientation that offers another lens to apply to pre-existing theories. It is not an alternative but instead a way to extend our current models, to promote change within them and as Foucault would say, make them "groan" (Foucault, 1980, pp. 53-54). For example, one could apply PAMT within CoMT, use it as a lens within anti-oppressive MT or combine with aspects of narrative therapy. Furthermore, I offer it as a starting point, a snapshot at a particular time in the understanding my practice. It is necessary for PAMT to remain open, flexible, and adaptable, in order for the disabled, neurodivergent, chronically ill and other diverse MT communities to determine how/if it should develop further.

I have used the term post-ableism as opposed to anti-ableism as the latter frames the practice in a more negative sounding way. As posthumanism is fundamentally optimistic in constructing new realities, it seems fitting for the term used to inspire practical (perhaps cautious) optimism and creation as well. However, like anti-ableism, I 
intend post-ableism to be a strategy, theory, action, and practice that challenges and counters ableism, inequalities, prejudices, and discrimination based on developmental, emotional, sensory, physical, neurological or psychiatric disability. I decided to not use an identity-based term as I recognise the diversity in how people identify, and I didn't want to be exclusive to any group or individual who also shared experiences of ableism.

I have tussled with the use of therapy in PAMT. Like previous MT authors, I too wonder whether therapy is the right word for describing what I do. Feminism offers a critique of the label of therapy as being problematic due to the link with the patriarchal association of psychotherapeutic and medical models of therapy (O'Grady \& McFerran, 2006). PAMT would also be implicated in this way, as there is an inextricable and longstanding history of ableism within medical and psychotherapeutic practices. However, I have left the word therapy for now whilst acknowledging its problems. I may or may not find the right alternative. Furthermore, because the analysis of my data highlighted that the dichotomy of client and therapist can lead to unequal power relations, re-labelling "clients" might help to subvert the dichotomy. To this end, it may be helpful at times to borrow the term "player" from Rickson and McFerran (2014) to apply to everyone involved in the process. They describe "player" as an all-inclusive term that equalises and helps to reduce the hierarchy inherent in role titles.

\subsection{Ableism}

Although I have given some definitions of ableism in the introduction, I wish to delve more into its various forms before going further into what PAMT might look like. This will provide more contextual framing for the vignettes to follow.

\subsubsection{Benevolent Ableism}

There are different types of ableism that lead to disablism, "the discriminatory, oppressive, or abusive behaviour arising from the belief that people who do not have certain abilities are inferior to others" (Wolbring, 2009, p. 151). These are benevolent, internalised, systemic, and individual. Benevolent ableism is often subtle and occurs when well-meaning people who don't intend to discriminate and intend to "help," are misguided by their own assumptions about what a disabled person needs and wants (Cameron, 2009).

Well-intentioned therapists may attempt to normalise people with disabilities so that they will assimilate in social settings, rather than offering alternative positions. Benevolent ableism occurs when MT organisations promote services for disabled people without consulting those they deem to be helping. Another example is when feelgood stories are used in promotions that frame MT and/or the therapist as the hero in the story and the client's disabilities are centralised. It occurs when condescending labels are used, such as differently-abled or special needs. Labels that are thought to make disability more palatable can instead be condescending and belittling.

\subsubsection{Internalised Ableism}

Internalised ableism occurs when negative understandings of disability are internalised and applied to the self. Not identifying as disabled due to negative associations, or not wanting to spend time with other disabled people for the fear of being associated as one of "them" may express this. ${ }^{17}$ Disabled people can often feel like a burden or undesirable as a result of internalised ableism.

Drawing on examples from my analysis, internalised ableism may also affect disabled therapists in the way of disclosure issues. Therapists may not identify as disabled in attempt to separate their role from that of the client. Internalised ableism may make a therapist view their disability negatively in relation to their practice, the maintenance of good practice being despite their disability instead of the possibility of good practice because of it. 


\subsubsection{Systemic and Institutional Ableism}

Systemic and institutional ableism occur within our social structures that do not allow disabled people to participate. For example, they can occur within educational structures. My analysis highlighted that accommodations can often be very hard to negotiate, and fairness is regularly related back to the normative body. A form of institutional ableism is increased bureaucratic demands. There is endless paperwork for disabled people and bureaucracy around specialist wait time, services one can access, and educational accommodations. The effort of wading through the bureaucracy does not always result in support. Only some of the students I work with get adequate funding for accommodations and services.

Accessibility is one of the main issues. Music opportunities can be inaccessible due to non-disabled being presumed. The significant under-representation of musicians with disabilities in the popular music industry might be partially counteracted by making music accessible at an educational level (Challis, 2009). Therapy services can also be inaccessible due to cost.

\subsubsection{Individual Ableism}

Individual ableism is often experienced through many microaggressions that build up over time. The term microaggressions, Derald Wing Sue (2010) points out, was coined by African American psychiatrist Chester M. Pierce in 1970. At a later date, Sue (2010) explains microaggressions as "brief, everyday exchanges that send denigrating messages to certain individuals because of their group membership" (p. xvi). Microaggressions were originally described in terms of racism but have been extended to encompass other marginalised groups' experiences by Sue (Sue, 2010; Sue \& Sue, 2015). Hadley (2017) draws attention to microaggressions in MT practice in her important self-reflective chapter, which introduced me to reading the earlier literature cited above.

There are three major categories of microaggressions: microassaults, microinsults, and microinvalidations (Hadley, 2017; Sue \& Sue, 2015). Microassaults are blatant intentional attacks of discrimination. Microinsults are comments or behaviours that unintentionally convey insensitivity or demean people. A microinsult example from my $\mathrm{PhD}$ analysis was the disregard of positive aspects of non-normative bodies and minds with statements like, "despite their disability." Finally, microinvalidations are behaviours or comments that dismiss, exclude, or negate the disabled person's experience, thoughts, and feelings (Sue \& Sue, 2015). They include the erasure and trivialisation of disabled peoples' experiences. Examples from my analysis include being told, "you don't look disabled," to just "have a positive mindset," and "eat a vegan diet" to "overcome" disability. This erases the ability to express a wide range of uncomfortable or confronting emotions, as there can be social backlash for marginalised voices that describe the realness of disability and disabling microaggressions. Microaggressions are usually invisible to the perpetrator, unintentional and unconscious, allowing the power dynamic within interactions to be maintained (Hadley, 2017).

I will now give further vignettes from my practice that demonstrate how the creation of less disabling environments can be supported in MT processes through the remaining focus areas: The removal of ableist barriers, supporting moments of connection, finding new and less restrictive spaces, and the therapist critically questioning their frame of reference.

\section{PAMT Vignettes}

\subsection{Vignettes Demonstrating the Removal of Ableist Barriers}

\subsubsection{Devang}

Devang spoke fast, tripping over his words. The beginnings and endings were sometimes missed: it was his way of speaking. One had to learn how to hear him. But even 
then, it was not always possible to decipher. He was referred to MT to learn the difference between fast and slow, in order to learn how to speak slowly and clearly. Devang loved to sing. I noticed that he was already aware of what fast and slow meant and that he could sing in a slow or fast manner, but his articulation of words wasn't always clear regardless of pace. One day he asked if he could write his own song. While discussing what he would like his song to be about, I picked up on some of his ideas, but also missed much of what he was saying. I asked if he could speak slower, like the slow song we just sung. He attempted. He got frustrated. I suggested singing his ideas musically. He attempted. He got frustrated. I offered ways to support him in altering his voice so that he could communicate what he wanted. He attempted. He got frustrated. The songs we wrote were not entirely his words. I incorrectly at times had to fill in the parts I couldn't understand. I was creating a barrier through the pursuit of verbal communication.

Understandably, he lost interest in songwriting after a few sessions. If I was working in neurorehabilitation some might say that he had lost motivation and became noncompliant in his voice work. Having witnessed the frustration he had experienced and the recognition of my role in this, I understood his need to say, "stuff it" and to take a break. Instead of trying to change his way of talking (reason for referral), I thought about how we could reduce the barriers that we faced in our communication. In talking with his speech and language therapist we offered Devang the use of touch chat (an iPad app) in his sessions. Through the use of technology, he was able to communicate what he wanted to say. During subsequent sessions he became an enthusiastic songwriter.

This is an example of supporting posthuman subjectivity by reducing barriers through our interdependence with non-human and human agents. Reducing the barriers of privileged normative speech to create a less disabling environment through valuing augmentative communication enabled Devang to be creative. This also engendered change in how school staff and students communicated with Devang. Touch chat was used in classroom groups and taken with Devang wherever he went.

Posthumanism was fundamental to this shift in approach as it countered the limitations of the humanistic ideal of independent communication--especially the privileging of normalised speech in the referral. It is interesting to note that MT critiques of humanism have not lessened its dominance in the way that critiques of the medical model have. Rolvsjord's (2010) critique of the medical model is comprehensive and far reaching. However, unlike the comparatively small amount of critiques of humanism in the MT literature, medical model critiques have sparked great changes to be made to practice. Orientations, such as CoMT, field of play, and ROMT, have developed in response and reposition practice away from the medical model. Likewise, I wish to respond to the contention of humanism by repositioning my practice and developing more pluralistic foundations. Therefore, I cannot stay within current MT orientations here, even those which developed in response to medical model critiques noted above, as humanism remains a dominant framework in such contemporary practices, despite its critiques. ${ }^{18}$

\subsubsection{Lucy}

Lucy could play the piano well and wanted to play with others in her school community. However, she was unable to read music, which the chamber music group relied on as the main way of learning pieces. We therefore focused our sessions on aurally learning the music, so she could feel confident in playing the pieces and become a chamber music group member. At a later time, the group leader asked how she could support Lucy by adapting her teaching methods. I talked with her about how she could make the group accessible, resulting in Lucy requiring less support from MT sessions.

This is an example of removing ableist barriers so that the student can access music making within her community. The community chamber group changed in response. For example, they got better at playing by ear and breaking the music into sections 
when learning, supporting the post-humanist value of interconnection. PAMT supports disabled people in accessing music making, without it having to have a non-musical therapeutic goal. The primary focus of Lucy's sessions was music making and ways to make this more accessible, not "the use of music to achieve non-musical goals." 19

This example demonstrates the importance of drawing on disability studies in PAMT, which is often underutilised or not fully embedded in other MT approaches. It is through such literature that I became more aware of the depth of societal and educational barriers disabled people face in accessing music making. While some MT approaches do give space for musical outcomes, despite some steps taken, there remains weak engagement between the fields, which Tsiris (2018) explores. Some connections did exist at the time I was writing my thesis (Gross, 2018; Hadley, 2014; Humpal, 2017; Metell \& Stige, 2015; Tsiris, 2013), but for the most part I found the voices of disabled scholars/communities and/or acknowledgement of political disabled identities to be missing in key books and articles where they would be well placed. Key scholars of disability studies in music such as Straus, Rowden, Lubet, McKay, and Cameron are missing in many MT texts. One example is Aigen's (2014) book, which readily discusses community, ecological and music-centered practices, but lacks a strong presence of scholars of disability studies in music and disabled communities and their identities, thus such approaches not being evidently formed by and with disabled voices. This is unfortunate given that such socio-cultural perspectives in MT have been presented as a way to bridge misunderstandings between disability studies and MT (Tsiris, 2018).

\subsection{Vignettes of Supporting Moments of Connection}

\subsubsection{Lucas}

Lucas used to watch the chimes move while other people played them. Sally, another group player, had just started working with Lucas and seemed unsure about what to do. She stated that she couldn't sing and sat and watched the others. Her interaction with Lucas during the group was minimal. I suggested that she could hold the chimes so that Lucas could play them. The position in which she held them was not the right angle for Lucas' movements. We worked together to find the best place for her to hold them. Lucas swung his hand to make them crash while squealing "eeeeee." "That's it Lucas," Sally encouraged. The next session Sally offered Lucas the chimes. She also started squealing "eeeeee" at the same time Lucas did. Lucas laughed when she did this, and it became a game that whole group participated in.

This is an example of how the less able aspects of oneself are viewed as a powerful source of connection in PAMT and how interconnected we are. Lucas required someone close to hold/position the chimes, and Lucas' different way of singing ("eeeee") provided Sally another way to use her voice during the session that was less song-like and less intimidating. It was, what could be viewed as, the incompleteness of Lucas' full range of movement and Sally's limited voice confidence that allowed this specific moment of connection to take place. The role of the therapist was to support how they could effectively work and create together.

\subsubsection{Patrice}

Patrice had shown a keen interest in my violin. I found a child-sized violin for her to use in sessions and also play throughout the week during break times from the classroom. We would improvise around the open string notes that she would bow. Patrice wanted to see the music we had made together, so I emailed some video clips to her parents for her to watch. Her father emailed back saying that the videos meant a lot to their family as Patrice's grandmother used to play the violin in orchestras. Her father contacted family to track down Patrice's Grandmother's old violin. ${ }^{20}$ He shared how he had unearthed a lot about their family history from doing this. Patrice's interest in the violin connected her with her family and engaged them in the process of discovering 
new possibilities for Patrice that situated her within stories of her ancestors, connecting with two aspects of Te Whare Tapa Wha ${ }^{21}$ in particular-whānau and wairua.

\subsection{Vignettes of Finding New and Less Restrictive Spaces}

\subsubsection{Hazel}

Hazel's music was off the beat, sliding between tones and keys as if to never rest anywhere. Free from form, key and beat, we played whatever, whenever, however, but always with a mischievous grin and always together. It made me think of a quote by Siebers:

Disability aesthetics refuses to recognize the representation of the healthy body-and its definition of harmony, integrity, and beauty-as the sole determination of the aesthetic. Rather, disability aesthetics embraces beauty that seems by traditional standards to be broken, and yet it is not less beautiful, but more so, as a result. (Siebers, 2010, p. 3) ${ }^{22}$

This was a less restrictive space. I did not provide a beat for her to entrain to or settle in a key for her to come home to. I did not use the Iso principle. I came to the music without an agenda, then began to play, musician to musician (Kenny, 2015). Hazel did not have to conform to the Western form of musical composition that deems "some notes consonant and others dissonant; some rhythms as falling on the beat and others off it" (Howe \& Jensen-Moulton, 2016, p. 526). She did not have to adhere to conformational practices that "dictate that one is either in tune or out of tune, blends with the ensemble or sticks out from it" (Howe \& Jensen-Moulton, 2016, p. 526). We celebrated every note, there was no hierarchy here: A supported disability aesthetics where Siebers (2010) describes how "the systemic oppression of disabled people would fail, and fail precisely because it could no longer be based on human appearances, features, and conditions deemed inferior" (Bakan, 2016, p. 548). Disability aesthetics considers cultural ideas and ideals of satisfaction and beauty through the lens of non-normativity (Howe \& Jensen-Moulton, 2016). By having an awareness of how music might enforce normalcy, I could understand how supporting Hazel's way of making music might reverse its dominance: perhaps even offering a disabled identity a place. The disabled aesthetic did not express defect but rather it enlarged "our vision of human variation and difference" (Siebers, 2010, p. 3). Such aesthetics and beauty can provide new, less restrictive spaces.

MT can therefore support one in escaping the dissonance between internal and external experiences and enable a space that might help to repair some of the injury of the chronic experience of misfit: the incongruity between mind, body and environment (Garland-Thomson, 2011). I hope that Hazel got a sense of that-from her motivation to create music we may have been on a helpful track. For me, I felt more "at home" in this music space.

Like in other vignettes, I drew heavily on understandings in disability studies to inform my practice here. In particular, the central role of music in embodying and shaping disability and normality, which emerge in mutually influential and parallel ways (Howe et al., 2015). This is important because music was found to be a conduit of disability knowledge and control in my analysis. Disability studies offer a plethora of further examples of how music institutions may construct disabled identities/subjectivities and the potential idea that "most standard music theories are not only normalising discourses but also disabling discourses" (Straus, 2011, p. 105). It is from this point that I temper Gross' (2018) view that music-centered MT is one example of a model that is sensitive to the social model of disability. It may be, but the primary focus on music does not automatically mean it is free from barriers or normalisation processes, which the social model draws attention to. I agree, however, that it may provide opportunities for mutuality if the therapist is aware of the power relationships in music making. Gross' article is none the less important because it adds to the conversation between disability studies and MT and draws attention to another disability model. Therefore, my caution is not to reduce its application in practice, more so as a 
reminder of the depths of ableism that can be present across orientations. Accordingly, drawing on music-centered approaches alone could not meet my concerns around the ableism encountered within music making in my practice.

\subsubsection{Penny}

Penny's teacher was concerned about what Penny would do after high school as she felt that Penny used her condition as an excuse to get involved in various things and focused on it too much in discussions. In MT she wanted to discuss the challenging aspects of pain (that was part of her condition), in between playing music-where she felt less pain for a short while. Penny felt silenced, "Nobody wants to understand, they don't want to hear how tough it is," she would say. Penny would request to sing, "Numb" by Linkin Park during these moments:

I'm tired of being what you want me to be

Feeling so faithless, lost under the surface

I don't know what you're expecting of me

Put under the pressure of walking in your shoes...

(Bennington, et al., 2003)

After these moments where Penny could tell me how it was for her, she would request to play free music together. She explained that during improvisations she did not notice the sensation of pain, it would "stop for a bit." Penny's sessions perhaps provided a less restrictive space from that of having to censor what she said about her pain as well as temporary relief from the restrictive sensations of pain. PAMT can address the ableism imbedded in the censoring of disabled voices to fit within social conventions that makes some conversations feel impossible. Many MT practices do support this well but it seems helpful to be explicit about the process.

It's important to notice that where my approach did perhaps differ, is that I did not seek to 'empower' Penny. Rather than speaking of an essentialist freedom, Foucault understood freedom and power as co-existing as relations that are observable as "actions upon other actions" (Foucault, 1982, p. 789). Thus, addressing ableism is not to support "empowerment" for the people we work with, as power is not a thing that one can own. Power exists in relationships in which it can be resisted or engaged and consequently placing the question of who benefits under scrutiny in social justice work. This differs to many social justice orientations proposed in MT that seek to empower clients, such as in Baines (2013) and Curtis (2012). Foucault spoke of an "agonism" in which there is reciprocal incitation and struggle; which isn't a confrontation that immobilises both sides but a productive permanent provocation of power (Foucault, 1982; Gordon, 1991). Agonism became an important aspect of the extended relational ethic in the development of PAMT. It was a generative site for personal transformation where my ethical care of the self was constructed through contestable and negotiated disability politics. In this vignette the discursive pair of music temporarily lessening pain (medical model of disability) and MT addressing the silencing of pain stories in social contexts (social model of disability), provided productive agonistic struggle within the therapeutic relationship. ${ }^{23}$

\subsection{Vignettes of Therapist Questioning Their Frame of Reference}

The following vignettes place value on disruptions in my thinking. Examples include when I perceived things as going wrong, when uncertainty was present, a new thought appeared, or when things were troubling/messy. This links with how the posthuman subject disrupts our vision of the human and that such disruptions are valued in posthumanism. Disability disrupts in the way that posthumanism does; the presence of disability "disrupts, shakes up and interrogates the normative position [...]. Disability inevitably disorientates normativity" (Goodley \& Runswick-Cole, 2014, p. 4). The following vignettes also demonstrate the need for a heightened reflexivity. As Baines 
(2013) explains, reflexivity is a political activity, as it uses what we think, say, and do as the material for transformation (Allan, 2006).

\subsubsection{Callum}

Callum said he wanted to continue MT next year. He wrote in his report, "I'd like to play better than I already can. I would like to play the games better and it also brings friendship up from other people and it means others want to come and play with me, which is actually really rare." Based on this, I continued to focus sessions around supporting relationships and social understanding.

During one session Callum showed an interest in writing a song on GarageBand. He struggled to work collaboratively with the other students as he had specific ideas about how he wanted it to sound. After the session, I asked him how he had found it. He said, "if I am working on my song, I do not want to bring anyone, because it makes it harder and they don't recognise the beat that I want. They are not mind readers." I initially thought, great he understands that they cannot possibly know exactly what he wants (which caused friction in prior sessions), but I felt that he still needed group sessions. I replied with, "Ok how about we alternate between one week with your friends and the other coming by yourself?" He responded, "No, how about the next month I come alone to work on my song." My initial reaction was to think that he had 'regressed' and to continue to try and hold a space for the group work.

On reflection, I reframed this as a progression in him understanding and voicing his needs and the need for me to support his way of being. I recognised that he doesn't have to like working with people all the time, and that he had voiced wanting to be alone sometimes. His way of being required more alone-time than my way of being. He came individually for the next five weeks and created a great piece of music he was happy with. The lyrics were:

There's hundreds of us! Some great others not,

we all do one thing and that's free run.

Vaulting and climbing in the urban world!

I'm not the greatest and definitely not the safest,

But I gotta deal with this pain as it only makes me better

Treader and netter, come on let's move

Free runners, we are free men, not held down by artificial weights, we are the people of a new world, a better world!

Now come on let's make that better world!

He expressed, during this song, a better world "not held down by artificial weights." Was I initially one of those weights? He shared this song with his friends in a subsequent session and it provided a tool for him to generate conversation.

As well as being an example of a disruption and shift in my thinking, it also exemplifies how our limitations can offer other possibilities: His new limits around group work were reframed as a possible site of growth in another area-musical development. This vignette demonstrates my struggle against trying to restore a normal self within a player who is not necessarily biologically configured in ways that will allow him to ever meet the requirements of being socially 'normal,' as these are currently constituted (Hodge, 2013). I shared my reflections and questions directly with him and within his notes, which parallels with the practice of narrative therapy.

\subsubsection{Marcus}

Marcus would get upset when having to leave the classroom on rainy days. At the time of working with him, I was grappling with moving away from humanism towards posthumanism. If I thought about his sessions with a humanistic framework, I considered how they supported his language and communication, in particular how it facilitated opportunities to practice speech clarity and increase verbal interactions (speech is venerated in humanistic thinking). I considered how I could support independence 
Table 2

Examples of potential key competency objectives for Marcus within humanism and posthumanism

\begin{tabular}{|l|l|l|}
\hline \multicolumn{2}{|c|}{ Humanism } & \multicolumn{1}{|c|}{ Posthumanism } \\
\hline $\begin{array}{l}\text { Managing } \\
\text { self }\end{array}$ & $\begin{array}{l}\text { Marcus would work towards independently go- } \\
\text { ing outside in the rain. }\end{array}$ & $\begin{array}{l}\text { Interconnected relationships would be } \\
\text { explored that may assist on rainy days. }\end{array}$ \\
\hline $\begin{array}{l}\text { Participating } \\
\text { and con- } \\
\text { tributing }\end{array}$ & $\begin{array}{l}\text { Would strive towards active participation as a } \\
\text { sign of success. }\end{array}$ & $\begin{array}{l}\text { Would celebrate both active and passive } \\
\text { participation. }\end{array}$ \\
\hline $\begin{array}{l}\text { Relating to } \\
\text { others }\end{array}$ & $\begin{array}{l}\text { Marcus would work towards furthering his so- } \\
\text { cial skills development and peer relationships: } \\
\text { Work towards having peers join him in sessions. }\end{array}$ & $\begin{array}{l}\text { To facilitate everyone's social under- } \\
\text { standing. To explore relationships with } \\
\text { multiple others (human and non-hu- } \\
\text { man) }\end{array}$ \\
\hline $\begin{array}{l}\text { Using lan- } \\
\text { guage sym- } \\
\text { bols and } \\
\text { text }\end{array}$ & $\begin{array}{l}\text { Work towards speech clarity and normalised } \\
\text { productions of speech (speech is venerated). }\end{array}$ & $\begin{array}{l}\text { Would support “an embodied and im- } \\
\text { pure activity based on noise, relationali- } \\
\text { ty, and reciprocity" (St. Pierre, 2015, p. } \\
\text { 330) }\end{array}$ \\
\hline $\begin{array}{l}\text { Thinking } \\
\text { To share thoughts, ask questions, independent- }\end{array}$ & $\begin{array}{l}\text { To support creativity and embrace dis- } \\
\text { abled aesthetics. }\end{array}$ \\
\hline
\end{tabular}

by providing a motivating activity for him to leave the classroom for, without being piggy-backed by me, so his feet didn't touch the water. I saw how his autonomy, when it was raining, was facilitated through his control of the music. But ultimately, I felt that disability was seen as only a "lack" when we worked towards such humanistic qualities.

Later viewing our sessions from a posthuman perspective, I considered how sessions could support enabling connections with human (me) and non-human entities: Technology enabled an amplification of his voice through a microphone and an iPad provided an enhanced memory recall of the experience through video that we looked at after the music finished. His exploration of the weather and how to coexist with this non-human element enhanced a relational consciousness with his environment, which is important for survival and health. Thus, acknowledging the environmental humannature relationship. Marcus was singing about his relationship with rain, sometimes liking it, sometimes unsure about it. I considered these moments of disruption as helpful, not as regression.

I felt that the posthuman reframing accepted his way of being. I could celebrate the interdependence of our music and more greatly appreciate that moments of anxiety around the rain were co-produced. For example, did we give Marcus enough time to fill his regulatory needs with self-calming behaviors on rainy days?

However, to situate this in an Aotearoa NZ education context, I was required to work within the key competencies of "managing self," "participating and contributing," "relating to others," and "using language symbols and text" (Ministry of Education, 2019), which are currently based on humanistic thinking. There is a strong drive in the competencies towards independence and self-management. Therefore, I needed to reframe and rework the key competencies with a posthuman perspective.

Some MT authors have pushed the parameters of humanism and one may wonder why I couldn't have just used these to frame my practice here. However, based on the findings of my research, the critical expansions of humanism proposed in the literature did not go far enough in addressing the power relations that create ableism. For example, Hadley and Thomas' (2018) critical humanism did not address the humannonhuman binary divide formed under humanism. The ontological divide between humans and non-humans has arguably been the deepest and most invisible hierarchy on which racist and sexist hierarchies, for example, have been grounded (Lennard \& 
Wolfe, 2017). Ableism sustains this divide and therefore we cannot adequately address social injustice without addressing it.

Ansdell and Stige (2018) do acknowledge the hierarchy of being and gap between human beings and non-human entities in their posthuman critique of humansim. However, they were perhaps unwilling to fully allow posthumanism a foundational place in MT practice. Instead they strongly proposed an extended humanism as the future conceptual spine for MT and denied posthumanism a proper seat at the table, as it was considered too "radical" (p. 6-7). I do not see its inclusion as a foundation for practice to be radical or discontinuous, particularly in an Aotearoa, New Zealand context. One can find hints of posthumanism in anything that decenters the human in relation to the world, such as the strong presence, connection and appreciation of the interrelatedness with non-human entities/environments in indigenous theories of practice (Kenny, 2015) and Māori models of health (Hodgson, 2014). Some definitions of MT include the role of non-human entities within therapeutic relationships (Bruscia, 2014). Ansdell and Stige (2018) themselves acknowledge aspects of posthuman thought in ecological and cultural models of therapy. Given that some aspects are present in current practice, embracing posthumanism as another foundation for practice would not be radical but instead support and value such practices, whilst also going beyond the limitations of humanism, thus allowing stronger agonistic pluralism. The counter-discourse of posthumanism is needed, as addressing ableism is more complex than simply incorporating disability issues into existing dominant frameworks. No matter how much it is extended, humanism has historically been hostile to disabled people and therefore another forum is needed.

This vignette utilised posthumanism to address the humanocentrism that often creates boundaries around the human subject. It demonstrates that posthumanism is not just a mode of critique, it has much potential as a position from which to practice and in generating greater agonistic provocation when given a more prominent place in practice. While the idea of expanding humanism is not new to MT practice, it seems that no theorist has fully embraced posthumanism as an active foundation for MT practice (at the time of writing my thesis). My research takes that necessary step in claiming posthumanism as an important foundation of PAMT. This has not been about abandoning humanism but developing the ability to re-position and move between different paradigms when needed. It will further allow the appreciation of many ways of being.

\subsubsection{Olive}

I do not like to admit this, but I had become bored working with Olive. I initially thought her repetitive music choices were the reason. I reflected later that my boredom arose partly through frustration at what seemed to be a repetitive therapy process with little change. Like most Western therapy, mine is embedded within a culture of transformation narratives, such as the formative account of Dibs and play therapy (Axline, 1964). In such narratives children with $\mathrm{ASD},{ }^{24}$ through therapeutic intervention, make miraculous breakthroughs into social and emotional normality (Fisher, 2007; Hodge, 2013). I was not experiencing such dramatic changes with Olive. Perhaps this made the sessions somewhat disappointing and less engaging for me personally? (Hodge, 2013). The problem of my boredom didn't stem from Olive's repetitive sameness but from larger social discourses and expectations.

\subsection{Further Thoughts on Vignettes}

I note that there are many more examples of using a PAMT orientation. PAMT is context-specific; therefore, it will change across contexts and therapists and might look quite different to the examples given here. I also acknowledge that even within the examples given there is room for growth and development in working in a post-ableist way. Indeed ableism is one I am still unpacking and find myself continually finding in 
hidden places. Nevertheless an extended relational ethic was important across all focus areas that may support the creation of a less disabling environment/experience.

\section{Conclusion}

This paper found that counteracting the ableism uncovered during the post-structural analysis of my experiences and practice could not simply be addressed through existing music therapy frameworks. I felt the imperative to develop an orientation of music therapy that specifically addressed ableism in an overt way. A creative journey unfolded, drawing on arts-based practices, to discover new ways to practice. PAMT was developed and extended the relational ethic beyond what was present in the practice studied by drawing on aspects of posthumanism (valuing interdependence), agonistic pluralism, and increasing the incorporation of disability studies. Due to the ableist tendencies of humanism, posthumanism was used as a foundation in PAMT, which differs to current MT orientations. No MT theories/orientations were found within the confines of the research that claimed and embraced posthumanism as a foundation for practice. Therefore, PAMT provides an alternative lens in the critical orientations' apparatus: a social justice practice that is not based on empowerment and humanism but instead on agonism and posthumanism. It is offered as a non-prescriptive starting point, as it is necessary for PAMT to remain open, flexible, and adaptable, in order for the disabled, neurodivergent, chronically ill and other diverse MT communities to determine how or if it should develop further.

\section{Acknowledgements}

I would like to acknowledge my supervisors Associate Professor Sarah Hoskyns and Associate Professor Sue Cornforth for their invaluable support and guidance.

I would like to thank Laura Kamau, Māori learning advisor for this research project: your ability and willingness to share Māori understandings of health offered such an important perspective.

I acknowledge and respect Te Tiriti o Waitangi (The Treaty of Waitangi) and seek to uphold and practice the core principles of partnership, participation and protection.

I would like to acknowledge the reviewers and Voices editors for their time and valuable feedback.

\section{About the Author}

Dr Carolyn Shaw (she/her) is a New Zealand Registered Music Therapist and teaching fellow at the New Zealand School of Music, Te Kōkī, Victoria University of Wellington, Aotearoa. Her music therapy practice has predominantly centred on working with children, their families, and schools. Carolyn has an interest in critical approaches, posthumanism and disability studies.

\section{Notes}

1. I refer to chronic illness as an impairment and disability in this article. Therefore, the terms disabled and illness are used interchangeably. When disability is considered to be dynamically produced by that which is physical/biological and that which is social, cultural and environmental, it made little sense to separate illness from disability. People with chronic illnesses are exposed to forms of social exclusion, disadvantage and disablism, like those with other impairments, whether or not they identify as disabled (Thomas, 2007). The terms "impairment" and "disability" are also used interchangeably due to the post-structural critique of impairment not being the sole domain of the body and mind and the inseparableness of impairment and disability. 
2. I note that I didn't always encounter ableism and that some work environments, particularly those that fostered inclusive education, were not discriminatory. I appreciated and enjoyed working in these places. However, whilst there was variability in contexts, subtle ableism had a strong presence.

3. Rosemarie Garland-Thomson (1997) coined the term "normate" to describe the veiled subject position of cultural self that is knowable from the deviant others that mark the normate's boundaries. The position emerges when we examine and critique the social processes and discourses that constitute otherness.

4. Disablism and ableism are sometimes used interchangeably. However, there can be differences in their understandings, with disablism referring to the direct experiences of discrimination and exclusion faced by disabled people, and ableism as the codes and social norms that shape our understandings of disability.

5. I am aware that other theories may address these issues, but I have noted orientations/theories that I drew on during the analysis and at this stage in the process. Therefore, theoretical approaches published after 2017, such as critical humanism (Hadley \& Thomas, 2018), have not been included here as they weren't available to me to draw on at the beginning of this journey.

6. Foucault spoke of an "agonism" in which there is reciprocal incitation and struggle; which isn't a confrontation that halts both sides but a productive permanent provocation of power (Foucault, 1982).

7. I have switched to writing in the present tense to give the reader a sense of journeying with me in the creative process.

8. I note that Ansdell and Stige's (2018) posthuman critique and Hadley and Thomas' (2018) critical humanism were published after the journey that I document here in developing PAMT (2016, until the beginning of 2018). They were published while I was writing up the discussion of my thesis and therefore they are discussed later in this article.

9. We cannot say with certainty that we have become posthuman or that we are only that - it is a process-oriented vision of the subject (Braidotti, 2013).

10. To read all examples of the creative writing pieces and improvisations, please refer to the full thesis (Shaw, 2019).

11. I acknowledge that this links with Jessica Benjamin's intersubjective "thirdness". She contends that the degree with which we ever manage to grasp two-way directionality is only from the place of the third, a vantage point outside the two.

12. Elaine Streeter, a UK music therapist and researcher, used to teach students to listen to the "unheard music" when learning to improvise (Guildhall School of Music and Drama).

13. I am making reference to Derrida's idea of différance here, refer to chapter 6 of my thesis (Shaw, 2019).

14. Data consisted of:

- Music therapy data: notes from MT sessions, MT literature, reflexive journal, notes from supervisors.

- Personal experience data: personal journal, medical records, compositions/music making, emails, photographs.

- External data: literature, disability blogs, codes of ethics, practice standards, school contracts, renewing practice certificate guidelines, ministry of education documents, and Kia orite (the national code of practice for tertiary education students with impairments in New Zealand).

15. Under the PAMT description below, I describe which disability definitions I am drawing on here. These are mainly social, cultural, and identity-based understandings. Accordingly, the focus on having an environment and experience that is less disabling is predominantly about addressing ableism. 
16. The myth of wholeness cannot be maintained by the imagined autonomous individual that has safe boundaries enabling unrestrictive self-determination when in the discursive space of disability (Rosemarie Garland-Thomson, 1997) or posthumanism. I became aware of the need for a new category of identity based on the partial, incomplete subject whose realisation is dependency and interdependence not independence and autonomy (Davis, 2013). I am not suggesting that disabled people are 'less than whole', instead I wish to point out that wholeness is a flawed way of understanding what it means human.

17. However, I also acknowledge that not identifying as disabled for reasons other than that of internalising negative associations does not mean that one has internalised ableism.

18. A further discussion of this can be found in Marcus' vignette.

19. A phrase often used in definitions of MT in NZ and one that I had previously used in explaining and presenting about MT.

20. This aspect of the work had many parallels with my own story of the violin. My Nana played the violin and when I was interested in learning to play it she had her violin repaired for me.

21. Te Whare Tapa Whā is a Māori model that understands health as a four-sided concept: te taha wairua (spirituality), te taha hinengaro (thoughts and feelings), te taha tinana (the physical side), te taha whānau (family) (Durie, 1985). These four aspects are interconnected.

22. Siebers' notes that he did not write the book Disability Aesthetics to represent the exclusion of disability from aesthetic history, because no such exclusion has taken place. Rather his intent was to make the influence of disability obvious. Similarly, I contend that music therapists have not excluded disabled aesthetics but rather that its generative and transformative potential is not always acknowledged. Siebers argues that beauty always maintains an underlying sense of disability and that it is this presence of disability that allows the beauty of the creative work to endure. This links with the Japanese aesthetics of wabi-sabi, where beauty is imperfect, incomplete and impermanent (English, 2016).

23. For more examples of agonism, please refer to my full thesis (Shaw, 2016).

24. I have used ASD here as it is referring to narratives within a medical model. I also note however, that some may people may prefer to identify as neurodivergent, autistic, or use the term Autism Spectrum Conditions. Bakan (2015) makes mention of the fact that autism spectrum conditions are usually referred to as autism spectrum disorders but the latter is less appropriate. Walker (2014) challenges pathologising autism as a "disorder" as to represent it in this way represents a value judgment rather than a fact. The neurodiversity movement understands autism as part of the spectrum of human biodiversity.

\section{References}

Aarø, L., \& Stige, B. (2012). Invitation to community music therapy. Routledge.

Aigen, K. (2005). Music-centered music therapy. Barcelona Publishers.

Aigen, K. (2014). The study of music therapy: Current issues and concepts. Taylor and Francis. https://doi.org/10.4324/9781315882703

Albrecht, G. (Ed.). (2006). Encyclopedia of disability. Sage Publications, Inc. https://doi.org/ $10.4135 / 9781412950510$

Allan, J. (2006). Inclusion as ethical practice. In S. Tremain (Ed.), Foucault and the government of disability (pp. 281-297). University of Michigan Press.

Ansdell, G. (2002). Community music therapy and the winds of change. Voices: A World Forum for Music Therapy, 2(2). http://doi.org/http://dx.doi.org/10.15845/voices.v2i2.83

Ansdell, G., \& Stige, B. (2018). Can music therapy still be humanist? Music Therapy

Perspectives, 36(1). http://doi.org/10.1093/mtp/miy018

Axline, V. (1964). Dibs, in search of self. Random House Publishing Group. 
Baines, S. (2013). Music therapy as an anti-oppressive practice. Arts in Psychotherapy, 40(1), 1-5. http://doi.org/10.1016/j.aip.2012.09.003

Bain, C., Grzanka, P., \& Crowe, B. (2016). Toward a queer music therapy: The implications of queer theory for radically inclusive music therapy. Arts in Psychotherapy, 50, 22-33. https://doiorg/10.1016/j.aip.2016.03.004

Bakan, M. (2015). Toward an ethnographic model of disability in the ethnomusicology of autism. In B. Howe, S. Jensen-Moulton, N. Lerner, \& J. Straus (Eds.), The Oxford handbook of music and disability studies (pp. 15-36). Oxford University Press.

Bakan, M. (2016). Music, autism, and disability aesthetics. Journal of the American Musicological Society, 69(2), 548-553.

Bennington, C., Shinoda, M., Hahn, J., Bourdon, R., Delson, B., \& Farrel, D. (2003). Numb [Song recorded by Linken Park]. On Meteora. Warner Bros.

Boylorn, R., \& Orbe, M. (2014). Introduction. In R. Boylorn \& M. Orbe (Eds.), Critical autoethnography: Intersecting cultural identities in everyday life (pp. 13-26). Left Coast Press, Inc.

Braidotti, R. (2013). The posthuman. Polity.

Bruscia, K. (2014). Defining music therapy (3rd ed.). Barcelona Publishers.

Cameron, C. (2009). Tragic but brave or just crips with chips? Songs and their lyrics in the disability arts movement in Britain. Popular Music, 28(3), 381-396. http://doi.org/10.1017/ S0261143009990122

Campbell, F. K. (2008a). Exploring internalized ableism using critical race theory. Disability and Society, 23(2), 151-162. http://doi.org/10.1080/09687590701841190

Campbell, F. K. (2008b). Refusing able(ness): A preliminary conversation about ableism. Media and Culture Journal, 11(3), 1-14. http://journal.media-culture.org.au/index.php/mcjournal/ article/viewArticle/46

Campbell, F. K. (2009). Contours of ableism: The production of disability and abledness. Palgrave MacMillan. http://doi.org/10.1080/10304311003797498

Campbell, F. K. (2014). Ableism as transformative practice. In C. Cocker \& T. HaffordLetchfield (Eds.), Rethinking anti-oppressive theories for social work practice (pp. 78-92). Palgrave MacMillan. https://doi.org/10.1007/978-1-137-02398-8_6

Challis, B. (2009). Technology, accessibility and creativity in popular music education. Popular Music, 28(3), 425-431. http://doi.org/10.1017/S0261143009990158

Chambers, S. (2001). Language and politics: Agonistic discourse in "The West Wing." Ctheory, a098a. http://www.ctheory.net/articles.aspx?id = 317

Cloyes, K. (2002). Agonizing care: Care ethics, agonistic feminism and a political theory of care. Nursing Inquiry, 9(3), 203-214. https://doi.org/10.1046/j.1440-1800.2002.00147.x

Curtis, S. (2012). Music therapy and social justice: A personal journey. The Arts in Psychotherapy, 39, 209-213. http://dx.doi.org/10.1016/j.aip.2011.12.004

Davis, L. (2013). Introduction: Disability, normality, and power. In L. Davis (Ed.), The disability studies reader (4th ed., pp. 1-16). Routledge: Taylor and Francis Group.

Durie, M. (1985). A Māori perspective of health. Journal of Social Science and Medicine, 20(5), 483-486. https://doi.org/10.1016/0277-9536(85)90363-6

Durie, M. (1998). Whaiora: Māori health development (2nd Ed.). Oxford University Press.

Ellis, C., Adams, T. E., \& Bochner, A. P. (2011). Autoethnography: An overview. Forum: Qualitative Social Research, 12(1), Art. 10.

English, Patricia. (2016). Imperfection: Embracing wabi-sabi. Liminalities: Tampa, 12(4), 1-9. http://liminalities.net/12-4/wabisabi.pdf

Erevelles, N. (2011). Disability and difference in global contexts: Enabling a transformative body politic. Palgrave McMillan.

Fisher, J. (2007). No search, no subject? Autism and the American conversion narrative. In M. Olsen (Ed.), Autism and representation (pp. 51-64). Routledge. 
Foucault, M. (1980). Power/knowledge: Selected interviews and other writings 1972-1977. (C. Gordon, Ed.). The Harvester Press.

Foucault, M. (1982). The subject and power. Critical Inquiry, 8(4), 777-795. https://doi.org/ $10.1086 / 448181$

Foucault, M. (1984). On the genealogy of ethics: An overview of work in progress. In P. Rabinow (Ed.), The Foucault reader: An introduction to Foucault's thought (pp. 340-372). Pantheon Books.

Garland-Thomson, R. (1997). Extraordinary bodies: Figuring physical disability in American culture and literature. Columbia University Press.

Garland-Thomson, R. (2011). Misfits: A feminist materialist disability concept. Hypatia, 26(3), 591-609. https://doi.org/10.1111/j.1527-2001.2011.01206.x

Goodley, D. (2010). Disability studies: An interdisciplinary approach. Sage Publications, Inc.

Goodley, D., Lawthom, R., \& Runswick-Cole, K. (2014). Post-human disability studies. Subjectivity, 7, 342-361.

Goodley, D., \& Runswick-Cole, K. (2014). Becoming dishuman: Thinking about the human through dis/ability. Discourse: Studies in the Cultural Politics of Education, 37(1), 1-15. http://doi.org/10.1080/01596306.2014.930021

Gordon, C. (1991). Governmental rationality. In G. Burchell, C. Gordon, \& P. Miller (Eds.), The Foucault effect: Studies in governmentality (pp. 1-52). Wheatsheaf.

Grant, A., Short, N., \& Turner, L. (2013). Contemporary British autoethnography. Sense Publishers.

Gross, R. (2018). The social model of disability and music therapy: Practical suggestions for the emerging clinical practitioner. Voices:A World Forum of Music Therapy, 18(1). https://doi.org/10.15845/voices.v18i1.958

Hadley, S. (Ed.) (2006). Feminist perspectives in music therapy. Barcelona Publishers.

Hadley, S. (2014). Shifting frames: Are we really embracing human diversities? Voices: A World Forum for Music Therapy, 14(3). http://doi.org/https://voices.no/index.php/voices/ article/view/801/666

Hadley, S. (2017). I don't see you as Black/Gay/Disabled/Muslim/etc.: Microaggressions in everyday encounters. In A. Whitehead-Pleaux \& X. Tan (Eds.), Cultural intersections in music therapy: Music, health, and the person (pp.11-22). Barcelona Publishers.

Hadley, S., \& Thomas, N. (2018). Critical humanism in music therapy: Imagining the possibilities. Music Therapy Perspectives, 36(1). http://doi.org/10.1093/mtp/miy015

Halifax, N. (2009). Disability and illness in arts-informed research: Moving toward postconventional representations. Cambria Press.

Hodge, N. (2013). Counselling, autism and the problem of empathy. British Journal of Guidance and Counselling, 41(2), 105-116. http://doi.org/10.1080/03069885.2012.705817

Hodgson, N. (2014). He oro hauora: How do kaupapa Māori models of health relate to my music therapy practice in an adolescent acute mental health unit? [Masters thesis, Massey University and Victoria University of Wellington].

Hoskyns, S. (2017). The place of improvisation in case study research in music therapy. The New Zealand Journal of Music Therapy, 15, 9-36.

Howe, B., Jensen-Moulton, S., Lerner, N., \& Straus, J. (2015). Introduction: Disability studies in music, music in disability studies. In B. Howe, S. Jensenmoulton, N. Lerner, \& J. Straus (Eds.), The Oxford handbook of music and disability studies (pp. 1-14). Oxford University Press. https://doi.org/10.1093/oxfordhb/9780199331444.001.0001

Howe, B., \& Jensen-Moulton, S. (2016). On the disability aesthetics of music. Journal of the American Musicological Society, 69(2), 525-563. https://doi.org/10.1525/ jams.2016.69.2.525

Humpal, M. (2017). The culture of disability. In A. Whitehead-Pleaux \& X. Tan (Eds.), Cultural intersections in music therapy: Music, health, and the person. Barcelona Publishers. 
Kalenderidis, Z. (2020). The great reveal: The experiences of an Australian registered music therapist with a disability, an arts-based research project. Voices: A World Forum for Music Therapy. 20(1). https://doi.org/10.15845/voices.v20i1.2873

Kenny, C. (2006). Music and life in the field of play: An anthology. Barcelona Publishers.

Kenny, C. (2015). Performing theory: Playing in the music therapy discourse. Journal of Music Therapy, 52(2), 457-486. http://doi.org/10.1093/jmt/thv019

Lee, C. (2003). The architecture of aesthetic music therapy. Barcelona Publishers.

Lennard, N., \& Wolfe, C. (2017, January). Is humanism really humane? The New York Times. https://www.nytimes.com/2017/01/09/opinion/is-\%20humanism-really-humane.html

Lubet, A. (2011). Music, disability, and society. Temple University Press.

McCaffrey, T., \& Edwards, J. (2015). Meeting art with art: Arts-based methods enhance researcher reflexivity in research with mental health service users. Journal of Music Therapy, 52(4), 515-532. http://doi.org/10.1093/jmt/thv016

McFerran, K. (2018). Critical thinking in disability and mental health: Where did it come from and what does it mean for music therapy practice? In Music Therapy Online.

https://musictherapyonline.org/p/critical-thinking

Metell, M., \& Stige, B. (2015). Blind spots in music therapy. Toward a critical notion of participation in context of children with visual impairment. Nordic Journal of Music Therapy, 25(4), 300-318. http://doi.org/10.1080/08098131.2015.1081265

Ministry of Education. (2019). Key competencies. Retrieved January 5, 2019, from http://nzcurriculum.tki.org.nz/Key-competencies

Morgan, A. (2000). What is narrative therapy?: An easy to read introduction. Dulwich Centre Publications.

Mouffe, C. (2016). Democratic politics and conflict: An agonistic approach. Política Común, 9. https://doi.org/10.3998/pc.12322227.0009.011

O'Grady, L., \& McFerran, K. (2006). Birthing feminist community music therapy. In S. Hadley (Ed.), Feminist perspectives in music therapy (pp. 63-80). Barcelona Publishers.

Oliver, M. (1996). Defining impairment and disability: Issues at stake. In C. Barnes \& G. Mercer (Eds.), Exploring the divide (pp. 29-54). The Disability Press.

Pickard, B. (2020). A critical reflection on the Health and Care Professions Council Standards of Proficiency for music therapists: A critical disability studies perspective. British Journal of Music Therapy, 34(2), 82-94. https://doi.org/10.1177\%2F1359457520971812

Pickard, B., Thompson, G., Metell, M., Roginsky, E., \& Elefant, C. (2020). It's not what's done, but why it's done: Music therapists' understanding of normalisation, maximisation, and neurodiversity movement. Voices: A World Forum for Music Therapy, 20(3).

https://voices.no/index.php/voices/article/view/3110/3068

Rickson, D., \& McFerran, K. (2014). Creating music cultures in the schools: A perspective from community music therapy. Barcelona Publishers.

Rolvsjord, R. (2010). Resource oriented music therapy: In mental healthcare. Barcelona Publishers.

Ruud, E. (2010). Music therapy: A perspective from the humanities. Barcelona Publishers.

Sampson, E. (2003). Unconditional kindness to strangers. Theory and Psychology, 13(2), 147-175. https://doi.org/10.1177/0959354303013002001

Siebers, T. (2010). Disability aesthetics. University of Michigan Press. https://doi.org/10.3998/ mpub.1134097

Shaw, C. (2019). Developing post-ableist music therapy: An autoethnography exploring the counterpoint of a therapist experiencing illness/disability [Doctoral thesis, Victoria University of Wellington, Wellington, New Zealand]. https://researcharchive.vuw.ac.nz/ xmlui/handle/10063/8247

Slattery, P. (2001). The educational researcher as artist working within. Qualitative Inquiry, 7(3), 370-398. http://dx.doi.org/10.1177/107780040100700307 
Small, C. (1998). Musicking: The meanings of performing and listening. Wesleyan University Press.

Sue, D. W. (2010). Microaggressions in everyday life: Race, gender, and sexual orientation. John Wiley \& Sons, Inc. http://doi.org/10.1177/0361684311401818

Sue, D. W., \& Sue, D. (2015). Counseling the culturally diverse: Theory and practice (7th ed.). John Wiley \& Sons, Inc.

St. Pierre, J. (2015). Cripping communication: Speech, disability, and exclusion in liberal humanist and posthumanist discourse. Communication Theory, 25, 330- 348. http://doi.org/ 10.1111/comt. 12054

Straus, J. (2011). Extraordinary Measures: Disability in music. Oxford University Press. http://doi.org/10.1093/acprof

Swain, J., \& French, S. (2000). Towards an affirmation model of disability. Disability \& Society, 15, 569-582.

Thomas, C. (2007). Sociologies of disability and illness: Contested ideas in disability studies and medical sociology. Palgrave MacMillan.

Tsiris, G. (2013). Voices from the "ghetto": Music therapy perspectives on disability and music (A response to Joseph Straus's book extraordinary measures: Disability in music). International Journal of Community Music, 6(3), 333-343. https://doi.org/10.1386/ ijcm.6.3.333_1

Tsiris, G. (2018, July 04-05). A misunderstood guest, a misunderstood host: Music therapy within disability studies [conference session]. Cripping the muse. Leeds, UK. https://crippingthemuse.com/contributors/

Viega, M., \& Forinash, M. (2016). Arts-based research. In B. Wheeler \& K. Murphy (Eds.), Music therapy research (3rd ed., pp. 491-504). Barcelona Publishers.

Walker, N. (2014). What is autism? Neurocosmopolitanism: Nick Walker's notes on neurodiversity, autism, and cognitive liberty. http://neurocosmopolitanism.com/what-isautism/

Wolbring, G. (2008). The politics of ableism. Development, 51, 252-258. http://doi.org/ 10.1057/dev.2008.17

Wolbring, G. (2009). What next for the human species? Human performance enhancement, ableism and pluralism. Development Dialogue, 2(August), 141-163.

Wolbring, G. (2012). Expanding ableism: Taking down the ghettoization of impact of disability studies scholars. Societies, 2, 75-83. http://doi.org/10.3390/soc2030075

World Health Organisation. (2011). World report on disability.http://www.who.int/disabilities/ world_report/2011/report.pdf 